\title{
IMPLEMENTASI PEMBELAJARAN DARING SEBAGAI REALISASI KEBIJAKAN PEMERINTAH DALAM SITUASI PANDEMI COVID-19 DI MAN 1 BULUKUMBA
}

\author{
${ }^{1 *}$ Mutmainna Kasaria, ${ }^{2}$ Suwardi Annas, ${ }^{3}$ Alin Liana \\ 1,2,3 Program Pascasarjana STKIP-PI, Makassar, Indonesia \\ *Email Korespondensi: kasariamutmanna@gmail.com
}

\section{INFO ARTIKEL}

Diterima 31 Oktober 2021 Direvisi 25 November 2021 Dipublikasikan 31 Desember 2021

\begin{abstract}
A B STRAK
Penelitian ini bertujuan untuk mengetahui implementasi pembelajaran daring serta faktor pendukung dan faktor penghambat dalam mengimplementasikan pembelajaran daring sebagai realisasi kebijakan pemerintah dalam situasi pandemi Covid-19 di MAN 1 Bulukumba. Penelitian ini merupakan penelitian kualitatif dengan menggunakan pendekatan kualitatif deskriptif. Subjek penelitian adalah kepala madrasah dan guru di MAN 1 Bulukumba. Pengumpulan data melalui observasi, wawancara, dan dokumentasi. Teknik analisis data yang digunakan pengumpulan data, reduksi data, penyajian data, kesimpulan dan verifikasi. Hasil penelitian menunjukkan bahwa penerapan pembelajaran daring di MAN 1 Bulukumba menggunakan media pembelajaran google classroom dan whatsapp, dengan membuat RPP darurat satu lembar. Materi pembelajaran yang diberikan mengacu pada kurikulum yang berlaku, karaktristik setiap siswa yang mengikuti pembelajaran daring berbeda-beda dilihat pada saat proses pembelajaran. Faktor pendukung implementasi pembelajaran daring meliputi: SDM (sumber daya manusia) yaitu guru dan peserta didik, sarana dan prasarana yang memadai (smartpnone, laptop, koneksi jaringan internet), dan manajemen pendidikan. Sedangkan faktor penghambat implentasi pembelajaran daring yaitu: masih ada siswa yang belum memiliki smartphone, dan tempat tinggal siswa yang jaringan internetnya kurang baik. Adapun media pembelajaran yang sangat berperan penting dalam proses pembelajaran daring di masa pandemi Covid-19 di MAN 1 Bulukumba yaitu google classroom dan whatsapp dengan memperhatikan kualitas SDM yang dimiliki, saran dan prasarana dan proses manajemen pendidikan.
\end{abstract}

Kata Kunci: Implementasi, Pembelajaran Daring, Kebijakan, Pemerintah

\section{IMPLEMENTATION OF ONLINE LEARNING AS A REALIZATION OF GOVERNMENT POLICIES IN THE COVID-19 PANDEMIC SITUATION IN MAN 1 BULUKUMBA}

\begin{abstract}
This study aims to find out how to implement online learning, what factors support the implementation of online learning, what factors are an obstacle in the online learning process as the realization of government policy implementation in the COVID-19 situation at MAN 1 Bulukumba. This research is a qualitative research using a descriptive qualitative approach. The research subjects were the principal and teacher at MAN 1 Bulukumba. data collection through observation, interviews, and documentation. The data analysis technique used was data collection, data reduction, data presentation, conclusion and verification. The results showed that the application of online learning at MAN 1 Bulukumba used the learning media of google classroom and whatsapp, by making one sheet of emergency lesson plans. The learning materials provided refer to the applicable curriculum, the characteristics of each
\end{abstract}


student who take part in online learning are different, seen during the learning process. Supporting factors for the implementation of online learning include: Human Resources (human resources), namely teachers and students, adequate facilities and infrastructure (smartphones, laptops, internet network connections), and education management. While the inhibiting factors for the implementation of online learning are: there are still students who do not have smartphones, and students' residences whose internet network is not good.

Keywords: Implementation, Online Learning, , Policy, Government

\section{Pendahuluan}

Pandemi COVID-19 berdampak pada seluruh sektor kehidupan, terutama di bidang pendidikan. Imbas dari munculnya virus ini di bidang pendidikan, membuat Menteri Pendidikan dan Kebudayaan (Mendikbud) mengeluarkan surat edaran Nomor 4 Tahun 2020 tentang pelaksanaan kebijakan pendidikan dalam masa darurat penyebaran COVID-19 Agar dapat memutus rantai penyebaran virus ini pemerintah menganjurkan untuk menutup kegiatan pembelajaran di sekolah dan menerapkan pembelajaran daring (online) di semua level pendidikan, termasuk di MAN 1 Bulukumba.

Dalam proses pembelajaran secara daring (online) ini memberikan banyak sekali dampak, mulai dari dampak positif hingga dampak negatif. Pembelajaran secara daring (online), guru dituntut untuk mempersiapkan pembelajaran yang baik dan kreatif dalam memberikan suatu materi, terutama dilingkungan Sekolah MAN 1 Bulukumba, dikarenakan di sekolah tersebut baru melaksanakan pembelajaran daring setelah adanya kebijakan pemerintah tentang pelarangan melakukan pembelarjaran secara tatap muka.

Berdasarkan hasil rapat sosialisasi pada tanggal 16 juli 2020 antara orang tua siswa dan guru MAN 1 Bulukumba, membahas tentang proses pembelajaran dalam masa pandemi COVID-19, agar terbentuk kerjasama yang baik antara orang tua dan guru dalam mencapai tujuan pembelajaran. Adapun pembahasan dalam pertemuan itu bahwa faktor utama yang sangat mempengaruhi proses pembelajaran secara daring ini adalah kekuatan jaringan internet serta faktor pendukungnya yaitu alat komunikasi seperti handphone yang memiliki fitur canggih, komputer atau laptop. Kualitas jaringan internet yang lemah membuat proses pembelajaran daring ini tidak berjalan secara maksimal. Akibatnya, beberapa siswa mengalami kesulitan dalam memahami materi pelajaran yang diberikan, sehingga pihak sekolah memberikan pilihan kepada siswa yang ingin mengikuti pembelajaran secara Daring dan pembelajaran secara Luring.

Penelitian yang telah dilakukan oleh Sadikin, (2020) dengan judul Pembelajaran daring di tengah wabah COVID-19. kajian ini membahas dan menganalisis gambaran pelaksanaan pembelajaran daring di Prodi Pendidikan Biologi FKIP Universitas Jambi sebagai upaya menekan penyebaran Covid-19 di Perguruan Tinggi. Penelitian yang dilakukan oleh Hamdani, (2020) dengan judul efektifitas implementasi pembelajaran daring (Full Online) di masa Pandemi Covid-19 Pada jenjang sekolah dasar di Kabupaten Subang, Penelitian ini membahas tentang pembelajaran daring penuh (full online) sebagai dampak dari Covid-19. Penelitian yang dilakukan oleh Dewi, (2020) dengan judul dampak Covid-19 terhadap implementasi pembelajaran daring di sekolah dasar. Kajian ini membahas tentang implementasi pembelajaran daring dirumah pada siswa sekolah dasar akibat dari adanya pandemi Covid-19. Sedangan penelitian yang saya lakukan yaitu implementasi pembelajaran daring sebagai realisasi kebijakan pemerintah dalam situasi pandemi Covid-19 di MAN 1 Bulukumba.

Berdasarkan konteks penelitian di atas, penulis telah melakukan penelitian tentang Implementasi pembelajaran daring sebagai realisasi kebijakan pemerintah dalam situasi pandemi Covid-19 di MAN 1 Bulukumba. Penelitian tersebut dilaksanakan untuk mengetahui bagaimana penerapan pembelajaran daring di MAN 1 Bulukumba. 


\section{Metode Penelitian}

Jenis penelitian ini kualitatif dengan pendekatan fenomenologi, subyek penelitian ini yakni kepala madrasah dengan guru MAN 1 Bulukumba. Untuk memperoleh data yang falid peneliti menggunakan tekhnik pengumpulan data melalui observasi yaitu dengan mengamati perilaku atau sitausi yang diamati dengan menggunakan observasi non-partisipan. Wawancara yaitu peneliti mengumpulkan informasi dari responden melalui interaksi verbal, sebelumnya peneliti menyiapkan daftar pertanyaan terstruktur yang berkaitan dengan penelitian. Peralatan dan perlengkapan yang dapat digunakan selama periode wawancara yaitu kertas, pulpen, laptop, tape recorder. Dokumentasi, adapun alat dokumentasi yang digunakan yaitu kamera. Wawancara dilakukan dengan mengajukan pertanyaan sebagai berikut, yakni: 1 ) Bagaimana implementasi pembelajaran daring sebagai realisasi pelaksanaan kebijakan pemerintah dalam situasi COVID-19 di MAN 1 Bulukumba?; 2) Apa yang menjadi faktor pendukung implementasi pembelajaran daring sebagai realisasi pelaksanaan kebijakan pemerintah dalam situasi COVID-19 di MAN 1 Bulukumba?; dan 3) Apa yang menjadi faktor penghambat implementasi pembelajaran daring sebagai realisasi pelaksanaan kebijakan pemerintah dalam situasi COVID-19 di MAN 1 Bulukumba?

\section{Hasil dan Pembahasan}

Proses penelitian ini dilakukan dengan mewawancarai narasumber. Dapat dilihat pada gambar 1 yang menunjukkan proses wawancara untuk menggali informasi terkait dengan penelitian.

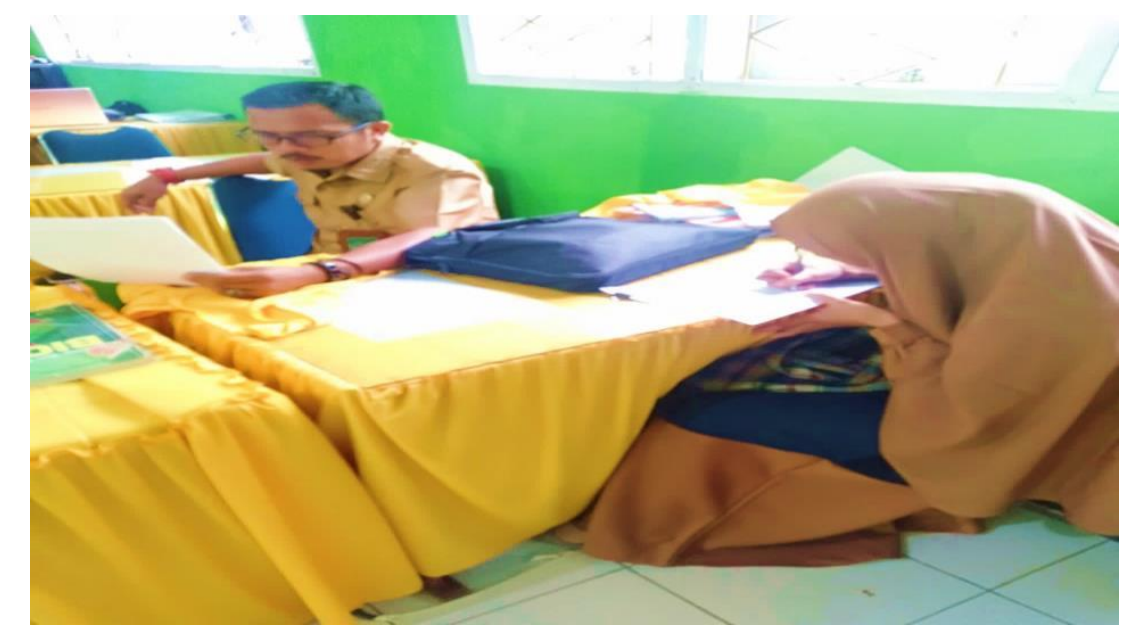

Gambar I. Foto peneliti saat mewawancarai narasumber

Berikut ini disajikan tabel 1 , yang memaparkan hasil wawancara dengan narasumber terkait dengan pertanyaan penelitian, mengenai implementasi pembelajaran daring sebagai realisasi pelaksanaan kebijakan pemerintah dalam situasi COVID-19 di MAN 1 Bulukumba.

Tabel I. implementasi pembelajaran daring sebagai realisasi pelaksanaan kebijakan pemerintah dalam situasi COVID-19 di MAN 1 Bulukumba

\begin{tabular}{cl}
\hline Nama & Hasil \\
\hline Sf & Menyatakan bahwa sesuai dengan surat edaran yang \\
& telah dikeluarkan oleh menteri pendidikan dan \\
& kebudayaan yang mengharuskan belajar dari rumah, \\
& maka upaya yang kami lakukan yaitu dengan \\
& memanfaatkan media pembelajaran berbasis online, \\
& yaitu pembelajaran daring dan kami juga
\end{tabular}




\begin{tabular}{ll}
\hline & $\begin{array}{l}\text { menggunakan model pembelajaran luring (luar } \\
\text { jaringan). }\end{array}$ \\
$\mathrm{Br}$ & $\begin{array}{l}\text { Menyatakan bahwa sudah pasti sebelum } \\
\text { melaksanakan proses pembelajaran terlebih dahulu } \\
\text { kami menyiapkan RPP darurat satu lembar sesuai } \\
\text { dengan arahan menteri pendidikan. }\end{array}$ \\
& $\begin{array}{l}\text { Menyatakan bahwa menyiapkan RPP satu lembar } \\
\text { sebelum memulai proses pembelajaran. }\end{array}$ \\
$\mathrm{Kh}$ & $\begin{array}{l}\text { Menyatakan bahwa Menyiapkan RPP satu lembar } \\
\text { sesuai dengan anjuran pemerintah. }\end{array}$ \\
$\mathrm{Ds}$ & $\begin{array}{l}\text { Menyatakan bahwa sebelum memulai proses } \\
\text { pembelajran terlebih dahulu menyiapkan RPP. }\end{array}$ \\
$\mathrm{Ir}$ & $\begin{array}{l}\text { Menyatakan bahwa RPP merupakan hal penting } \\
\text { dalam proses pembelajaran, RPP yang digunakan yaitu } \\
\text { RPP darurat satu lembar }\end{array}$ \\
&
\end{tabular}

Berikut ini disajikan tabel 2, yang memaparkan hasil wawancara dengan narasumber terkait dengan pertanyaan penelitian, mengenai hal yang menjadi faktor pendukung implementasi pembelajaran daring sebagai realisasi pelaksanaan kebijakan pemerintah dalam situasi COVID-19 di MAN 1 Bulukumba.

Tabel II. Faktor pendukung implementasi pembelajaran daring sebagai realisasi pelaksanaan kebijakan pemerintah dalam situasi COVID-19 di MAN 1 Bulukumba

\begin{tabular}{|c|c|}
\hline Nama & Hasil \\
\hline Sf & $\begin{array}{l}\text { Menyatakan bahwa faktor pendukung dalam } \\
\text { pelaksanaan pembelajaran daring yaitu faktor dar } \\
\text { tenaga pendidik itu sendiri(guru), peserta } \\
\text { didik"(siswa), smartphone, laptop, dan koneksi } \\
\text { jaringan internet. }\end{array}$ \\
\hline B & $\begin{array}{l}\text { Menyatakan bahwa ketersediaan sarana dan prasana } \\
\text { menjadi faktor penting dalam mendukung proses } \\
\text { pembelajaran daring di MAN } 1 \text { bulukumba seperti alat } \\
\text { komunikasi, koneksi jaringan internet yang } \\
\text { mendukung kelancaran prose pembelajaran, SDM } \\
\text { (sumber daya manusia) juga merupakan salah satu } \\
\text { faktor pendukung yaitu guru siswa, manajemen } \\
\text { pendidikan yang baik. }\end{array}$ \\
\hline $\mathrm{Mh}$ & $\begin{array}{l}\text { Menyatakan bahwa faktor pendukung yaitu guru dan } \\
\text { peserta didik itu sendiri. }\end{array}$ \\
\hline K & $\begin{array}{l}\text { Menyatakan bahwa ketersediaan sarana dan prasana } \\
\text { menjadi faktor penting dalam mendukung proses } \\
\text { pembelajaran daring di MAN } 1 \text { bulukumba seperti alat } \\
\text { komunikasi, koneksi jaringan internet yang } \\
\text { mendukung kelancaran prose pembelajaran, SDM }\end{array}$ \\
\hline
\end{tabular}


(sumber daya manusia) juga merupakan salah satu faktor pendukung yaitu guru siswa, manajemen pendidikan yang baik.

Ds

Menyatakan bahwa faktor pendukung dalam pelaksanaan pembelajaran daring yaitu jaringan internet dan ketersediaan alat yaitu smartphone.

Ir

Menyatakan bahwa faktor pendukung yaitu dari pihak guru, sisa, sarana dan prasarana yang memadai.

Berikut ini disajikan tabel 3, yang memaparkan hasil wawancara dengan narasumber terkait dengan pertanyaan penelitian, mengenai hal yang menjadi faktor penghambat implementasi pembelajaran daring sebagai realisasi pelaksanaan kebijakan pemerintah dalam situasi COVID-19 di MAN 1 Bulukumba.

Tabel III. Faktor penghambat implementasi pembelajaran daring sebagai realisasi pelaksanaan kebijakan pemerintah dalam situasi COVID-19 di MAN 1 Bulukumba

\begin{tabular}{|c|c|}
\hline Nama & Hasil \\
\hline Sf & $\begin{array}{l}\text { Menyatakan bahwa faktor penghambat/kendala } \\
\text { dalam pelaksnaan pembelajaran daring yaitu masih } \\
\text { ada siswa yang belum memiliki smartphone, tempat } \\
\text { tinggal siswa yang tdk terjangkau jaringan internet } \\
\text { yang baik, kurangnya motivasi dari orang tua karena } \\
\text { sibuk bekerja. }\end{array}$ \\
\hline B & $\begin{array}{l}\text { Menyatakan bahwa masih ada Siswa yang belum } \\
\text { memiliki smartphone/kondisi sarana yang kurang } \\
\text { memadai, kondisi jaringan di tempat tinggal siswa } \\
\text { kurang memadai, kurangnya dukungan dari orang tua } \\
\text { wali peserta didik karena sibuk bekerja. }\end{array}$ \\
\hline $\mathrm{Mh}$ & $\begin{array}{l}\text { Menyatakan bahwa koneksi jaringan internet kurang } \\
\text { baik di tempat tinggal siswa. }\end{array}$ \\
\hline K & $\begin{array}{l}\text { Menyatakan bahwa masih ada Siswa yang belum } \\
\text { memiliki smartphone/kondisi sarana yang kurang } \\
\text { memadai, kondisi jaringan di tempat tinggal siswa } \\
\text { kurang memadai, kurangnya dukungan dari orang tua } \\
\text { wali peserta didik karena sibuk bekerja. }\end{array}$ \\
\hline Ds & Menyatakan bahwa Sarana yang kurang memadai \\
\hline $\operatorname{Ir}$ & $\begin{array}{l}\text { Menyatakan bahwa faktor penghambat masih ada } \\
\text { siswa yang belum memiliki smartphone, koneksi } \\
\text { jaringan internet yg kurang baik di tempat tinggal } \\
\text { siswa. Solusi yang diberikan yaitu siswa yang tidak } \\
\text { memiliki smartphone bisa mengikuti pembelajaran } \\
\text { luring di sekolah sesuai dgn jadwal yg ditentukan } \\
\text { dengan tetap memperhatikan protoko kesehatan. }\end{array}$ \\
\hline
\end{tabular}


Implementasi pembelajaran daring di MAN 1 Bulukumba dilandasi dengan adanya surat edaran Mendikbud No 4 tahun 2020 tentang pelaksanaan kebijakan pendidikan dalam masa darurat penyebaran corona virus deseas (COVID-19). Dari surat edaran tersebut upaya yang dilakukan Kepala Madrasah MAN 1 Bulukumba yaitu dengan memanfaatkan media pembelajaran berbasis online atau yang sering disebut dengan pembelajaran daring. Berdasarkan teori yang dikemukakan oleh Ivanova et al (2020) pembelajaran daring artinya adalah pembelajaran yang dilakukan secara online, menggunakan aplikasi pembelajaran maupun jejaring sosial. Pembelajaran daring merupakan pembelajaran yang dilakukan tanpa melakukan tatap muka, tetapi melalui platform yang telah tersedia. Segala bentuk materi pelajaran didistribusikan secara online, komunikasi juga dilakukan secara online, dan tes juga dilaksanakan secara online. Sistem pembelajaran melalui daring ini dibantu dengan beberapa aplikasi, seperti Google Classroom, Google Meet, Edmudo dan Zoom cloud meeting.

Faktor pendukung adalah semua faktor yang sifatnya turut mendorong, menyokong, melancarkan, menunjang, membantu, mempercepat dan sebagainya terjadinya sesuatu. Faktor pendukung dalam implementasi pembelajaran daring di MAN 1 Bulukumba adalah:

1. Manajemen Sekolah: Manajemen merupakan sesuatu runtutan perubahan (peristiwa) dalam perkembangan sesuatu melalui perencanaan, pengorganisasian, pemimpinan, dan pengendalia (KBBI online, 2020). Menurut Satori (1980) manajemen pendidikan merupakan keseluruhan proses kerjasama dengan memanfaatkan sumber personel dan material yang tersedia dan sesuai untuk mencapai tujuan pendidikan yang telah ditetapkan secara efektif dan efisien (Yunandra, 2019: 20).

Dalam pelaksanaan manajemen pendidikan ini kepala sekolah MAN 1 Bulukumba mewajibkan setiap guru mengirimkan bukti atau laporan setelah melakukan pembelajaran daring sehingga kepala sekolah bisa memonitoring secara langsung.

2. Pendidik/ Guru: Posisi guru adalah pengajar, pemyampain, pemberi contoh, perubah dari hal yang tidak baik kepada hal yang baik terutama dari sisi pengetahuan (Almandili, 2020: 14). Dengan demikian, kompetensi yang dimiliki oleh setiap guru akan menunjukkan kualitas guru yang sebenarnya (Direktorat Tenaga Kependidikan Depdiknas, 2003). Sementara itu, kompetensi menurut Kepmendiknas 045/U/2002 adalah seperangkat tindakan cerdas, penuh tanggung jawab yang dimiliki seeorang sebagai syarat untuk dianggap mampu oleh masyarakat dalam melaksanakan tugas-tugas di bidang pekerjaan tertentu.

Kemampuan guru dalam memilih metode pembelajaran dan keterampilannya dalam mengoperasionalkan aplikasi pembelajaran online sangat mendukung proses pembelajaran daring. Semua guru MAN 1 Bulukumba mampu mengoperasionalkan aplikasi WhatsApp meskipun belum maksimal dan semua guru dalam memilih bahan ajar serta metode sudah sesuai dengan kurikulum. Terlihat dari Rencana Pelaksanaan Pembelajaran (RPP).

3. Peserta didik: Menurut Sanjaya (2006:52) kemampuan belajar siswa dapat dikelompokkan pada siswa berkemampuan tinggi, sedang, dan 64 rendah. Siswa yang termasuk berkemampuan tinggi biasanya ditunjukkan oleh motivasi yang tinggi dalam belajar, perhatian dan keseriusan dalam mengikuti pelajaran dan lain sebagainya.

\section{Kesimpulan}

Kondisi saat Ini mengharuskan pendidik tetap melaksanakan pembelajaran dengan memanfaatkan media pembelajaran berbasis online/daring. Pendidik diharapkan dapat menyampaikan materi pembelajaran dengan detail dan memaparkan dengan jelas agar peserta didik mudah memahami materinya walaupun tidak dijelaskan seperti di dalam kelas. Implementasi pembelajaran daring di MAN 1 Bulukumba dapat dikatakan berjalan dengan baik karena memanfaatkan media pembelajaran berbasis online dengan menggunakan media pembelajaran seperti Google classroom dan WhatsApp. Dalam perencanaannya guru membuat RPP (Rencana Pelaksanaan Pembelajaran), dalam pelaksanaannya guru menggunakan metode daring/online dan luring/luar jaringan. prosesnya menggunakan media aplikasi WA (Whatsapp) yang mana pendidik membuat group sesuai dengan pelajaran yang diampuhnya, kemudian ada group perkelas antar wali kelas dan peserta didik untuk berdiskusi ketika ada keperluan. Pengambilan 
nilai/evaluasi pada proses pembelajaran daring dilaksanakan melalui pengumpulan hasil tugas terstruktur dan tugas tidak terstruktur. Faktor Pendukung Implementasi Pembelajaran Daring Sebagai Realisasi Kebijakan Pemerintah Dalam Situasi COVID-19 di MAN 1 Bulukumba. Faktor pendukung implementasi pembelajaran daring di MAN 1 Bulukumba meliputi: Manajemen sekolah, Pendidik/guru, Peserta didik. Sedangkan faktor Penghambat Iplementasi Pembelajaran Daring Sebagai Realisasi Kebijakan Pemerintah Dalam Situasi COVID-19 di MAN 1 Bulukumba meliputi: Masih ada peserta didik yang belum memiliki smartphone dan koneksi jaringan yang kurang bagus ditempat tinggal peserta didik.

Mengingat banyaknya macam-macam media yang bisa digunakan untuk pembelajaran daring maka pihak sekolah perlu memberi arahan kepada guru untuk menggunakan media yang bervariasi, Sekolah memfasilitasi alat yang digunakan dalam pembelajaran daring. Bagi guru: Guru menggunakan media pembelajaran yang bervariasi agar peserta didik tidak merasa bosang belajar di rumah. Media audio, video, visual, serbaneka, ataupun menggunakan aplikasi media pembelajaran daring yang telah bekerjasama dengan Kemendikbud. seperti rumah belajar, meja kita, icando, indonesix, google fo education, kelas pintar, quipper dan juga menggunakan youtub. Bagi peserta didik: Peserta didik harus lebih aktif dalam mengikuti pembelajaran, Peserta didik belajar mengoperasionalkan media pembelajaran dengan searching di youtube tutorialnya, Peserta didik berusaha untuk mempunyai alat untuk mengikuti pembelajaran daring, setidaaknya dengan nisa ikut belajar dengan teman yang memiliki Smartphone.

\section{Referensi}

Dewi, W. A. F. (2020). Dampak COVID-19 terhadap Implementasi Pembelajaran Daring di Sekolah Dasar. Edukatif: Jurnal IImu Pendidikan, 2(1), 55-61. https://doi.org/10.31004/edukatif.v2i1.89

Khusniyah, N.L., \& Hakim, L. (2019). Efektivitas Pembelajaran Berbasis Daring: Sebuah Bukti Pada Pembelajaran Bahasa inggris. JurnalTatsqif, 17(1),19-33. https://doi.org/10.20414/itq.v17i1.667

Naserly, M. K. (2020). Implementasi Zoom, Google Classroom, Dan Whatsapp Group Dalam Mendukung Pembelajaran Daring (Online) Pada Mata Kuliah Bahasa Inggris Lanjut. Journal of Chemical Information and odeling, 4(2),55165. https://jurnaldikpora.jogjaprov.go.id/ index.php/jurnalideguru/article/view/129

Nugroho,A.,Puspitasari, R., \& Puspitasari, E. (2016). Implementasi Gemar Membaca Melalui Program PojokBacaDalamMataPelajaranIpsPadaSiswaKelasViiiDiSmpn2Sumber.Edueksos,5(2),187206.http://do wnload. portalgaruda.org/article. php?article $=471297 \&$ val $=9452 \&$ titl

Rahmat, D. (2017). Implementasi Kebijakan Program Bantuan Hukum Bagi Masyarakat Tidak Mampu Di Kabupaten Kuningan. UNIFIKASI: Jurnal IImu Hukum, 4(1), 3542. https://doi.org/10.25134/unifikasi.v4i1.478

Roni Hamdani, A., \& Priatna, A. (2020). Efektifitas Implementasi Pembelajaran Daring (Full Online) Dimasa Pandemi Covid- 19 Pada Jenjang Sekolah Dasar Di Kabupaten Subang. Didaktik : Jurnal Ilmiah PGSD STKIP Subang, 6(1), 1-9. https://doi.org/10.36989/didaktik.v6i1.120

Sadikin, A., \& Hamidah, A. (2020). Pembelajaran Daring di Tengah Wabah Covid-19. Biodik, 6(2), 109-119. https://doi.org/10.22437/bio.v6i2.9759

Suhendro, D. (2017). Perancangan dan Implementasi Realisasi Anggaran Pendapatan ( Studi Kasus: Pengadilan Negeri Klas IB Pematangsiantar ). Seminar Nasional Teknologi Informatika, 30-36.Nurdin Usman. (2002). Konteks Implementasi Berbasis Kurikulum. Jakarta: PT Raja Grafindo Persada Purba, J. F., Tarigan, U., Nasution, I., \& Suharyanto, A. (2019). Implementation of the Population Administration information system in electronic Resident card management. Perspektif, 8(2), 77-83. 
Syarifudin, A. S. (2020). Impelementasi Pembelajaran Daring Untuk Meningkatkan Mutu Pendidikan Sebagai Dampak Diterapkannya Social Distancing. Jurnal Pendidikan Bahasa Dan Sastra Indonesia Metalingua, 5(1), 31-34. https://doi.org/10.21107/metalingua.v5i1.7072 